\title{
Feminist Theory
}

http://fty.sagepub.com

\section{Gender justice and the welfare state in post-communism Anca Gheaus}

Feminist Theory 2008; 9; 185

DOI: $10.1177 / 1464700108090410$

The online version of this article can be found at: http://fty.sagepub.com/cgi/content/abstract/9/2/185

\section{Published by: (-) SAGE}

http://www.sagepublications.com

Additional services and information for Feminist Theory can be found at:

Email Alerts: http://fty.sagepub.com/cgi/alerts

Subscriptions: http://fty.sagepub.com/subscriptions

Reprints: http://www.sagepub.com/journalsReprints.nav

Permissions: http://www.sagepub.co.uk/journalsPermissions.nav

Citations (this article cites 8 articles hosted on the SAGE Journals Online and HighWire Press platforms):

http://fty.sagepub.com/cgi/content/refs/9/2/185 


\title{
Gender justice and the welfare state in post-communism
}

Anca Gheaus Universite Catolique de Lille

\begin{abstract}
Some Romanian feminist scholars argue that welfare policies of post-communist states are deeply unjust to women and preclude them from reaching economic autonomy. The upshot of this argument is that liberal economic policy would advance feminist goals better than the welfare state. How should we read this dissonance between Western and some Eastern feminist scholarship concerning distributive justice? I identify the problem of dependency at the core of a possible debate about feminism and welfare. Worries about how decades of communism have shaped citizenry feed feminists' suspicion of the welfare state and fears of paternalist policies. I criticize the arguments in favour of neoliberal policies and I suggest a crucial distinction between legitimate, universal forms of human dependency and dependencies that result from particular social arrangements.
\end{abstract}

keywords care, gender justice, Romania, welfare state

\section{Introduction}

Western feminist philosophers - such as Joan Tronto (1993; White and Tronto, 2004), Diemut Bubeck (1995, 1999), Eva Kittay (1999) and Anne Alstott (2004) - have been arguing for many decades in favour of distributing dependency work through state institutions as a matter of gender justice. They have advanced compelling arguments and practical proposals regarding various mechanisms for redistributing care via public institutions. ${ }^{1}$ In addition, scholars as different as Martha Nussbaum (2006) and Alison Jaggar (2005) have recently put forward arguments against neoliberal globalization which they claim is bad for women. Their arguments are meant to support the welfare state and defend it against libertarian attacks.

By contrast, recent Romanian feminist scholars, mainly Mihaela Miroiu (2003, 2004), show how the current welfare policies of post-communist ${ }^{2}$ states are noxious to women. The central claim is that the Romanian welfare state in its current form mostly provides well-paid state jobs and social security nets for men, with money collected from taxes that are mainly paid by women (this argument will be further developed and 
explored in the fourth section of this paper). As a result, the redistribution is deeply unjust to women and precludes them from reaching economic autonomy. At the same time, according to this argument, a redistribution of poverty - rather than wealth - precludes women from developing a feminist consciousness and setting the basis of a feminist grass-roots movement. The upshot of this argument is that a more laissez-faire economic policy would advance feminist goals better than the welfare state by encouraging the formation of a class of successful, independent women. ${ }^{3}$

How should one interpret this dissonance between Western and Romanian feminist scholarship? Do the two sets of arguments really reflect a different political ethos? Are they the result of differences between Western and East European institutional set-ups, or do they reflect different stages of modernization?

My aim in this article is to analyse critically recent work by Romanian scholars on the impact of the post-communist welfare state on gender justice, and provide some explanation for the divergence between some of the feminist scholarship produced in the East from its Western counterpart. By paying close attention to the peculiarities of Romanian communism and post-communism, I explain how it is possible for feminism and neoliberal ideology - as adopted by the post-communist countries of Central and Eastern Europe - to meet on a common ground. I argue that differences in the design of state institutions, the malfunctioning of these institutions and the anti-statist ethos widespread in post-communist societies have shaped their political culture. This can make more comprehensible the contrasts between the feminist theory produced in the East and that produced in the West. At the same time, I reject the claim that liberalization can truly advance feminist goals.

The methodology used in this article is textual exegesis: I analyse theoretical literature from several Central and Eastern European countries, but I do not engage directly with either quantitative or qualitative research. In the unfolding of the argument, I compare Romanian literature with similar literature from Hungary, another country that was part of the communist block and is undergoing similar economical and political post-communist transformations as Romania. Hungarian scholars have advanced similar, but more nuanced, hypotheses concerning the situation of women on the post-communist market, with different normative conclusions. ${ }^{4}$ A comparison between Romania and Hungary is relevant because they are representative of two models of development in post-communist Europe. Romania, on the one hand, is a case of the less economically developed and more politically conservative Central and Eastern European countries, having undergone a particularly oppressive form of communism. On the other hand, Hungary had a faster post-communist development towards liberalization and is the heir of a more liberal communist regime.

My own hypothesis is that at the core of a (possible) debate about welfare between Eastern European and Western scholars lies the problem of dependency. At the end of the paper I suggest a way to deflate some of the contradictions between Eastern and Western scholarship by drawing a distinction 
between legitimate dependency (of the kind which will always be with us) and dependencies that we can hope (and should aim) to eliminate through institutional arrangements.

Before moving on to discuss the post-communist literature on the welfare state, let me review some (highly theoretical) proposals for redistributing care, coming from Western feminist political philosophers. This will serve as a background for the further discussion and also as a connecting point for the final section in which I look at the problem of dependency.

\section{Western feminism: the case for the redistribution of care}

In a nutshell, the argument in favour of redistributing care is that justice requires a fair sharing of all burdens of social cooperation; conceptualized as a form of work, caregiving is a central, indispensable type of social burden. Its redistribution, then, is a matter of justice (and not merely of humanitarian concern, or charity, as welfare is often depicted by conservatives), and given the historical association between women and care, a matter of gender justice.

Amongst the Western feminists advocating the redistribution of care and suggesting concrete ways of doing this, two philosophical accounts, those of Bubeck (1995, 1999) and Kittay (1999), are particularly helpful for thinking about caregiving as a matter of distributive justice. By looking at care and justice in the context of the dynamics of gender relations, Bubeck presents care as every citizen's duty. She reveals the exploitative nature of the historical distribution of the care work within the family and thus the injustice of current arrangements for women who bear a double burden in social cooperation. Bubeck's practical proposal is the creation of a staterun social service of caregiving, which would be similar to, or even replace, military service. The service would be mandatory for all citizens who, at some point in their lives, would have to provide care to others. It would entail that each citizen of a given community has to work for a couple of years - typically in one's youth - as a caregiver in one of the institutions which provide care: hospitals, day-care centres, homes for the elderly and so on. ${ }^{5}$

Kittay, in turn, proposes to add care to the list of Rawlsian primary goods in order to provide a solid justification for a state-run welfare system and thus avoid the exploitation of caregivers. By supporting individual caregivers, paid or unpaid, through economic incentives, a political community would give due recognition both to the importance of care and to those people who most often provide it.

In Bubeck's, as well as in Kittay's, theory care is a matter of justice and therefore its management is a question of public interest. Far from being at odds, the values of justice and care require each other. I shall briefly return to their proposals of redistributing care in the last section of this paper, since they are helpful in the context of discussing ways to provide for legitimate dependency while making space, at the same time, for a reform of the welfare state. 
In domestic politics, feminists from the West uncompromisingly defend the necessity of welfare states as a matter of justice for women. ${ }^{6}$ Within a large body of scholarship on this issue, there is, of course, scope for debating exactly which shape the welfare state should take. For example, opinions are divided as to whether various benefits such as pensions should be family-based or individual-based. Another question regards the kinds of support that are most adequate for women - or parents - with small children so that women have a genuine choice between staying at home to look after their children and continuing to work and relying on publicly funded day care and kindergartens. ${ }^{7}$ Different models of welfare with respect to caregiving have recently emerged, one presenting the citizen as worker with the state as the main provider of care, the other representing the citizen as both worker and (temporary) caregiver (PfauEffinger, 2005).

Irrespective of one's particular stance on these issues, feminist philosophers and political theorists agree that women's well-being requires a welfare state supported by a level of redistribution which is high enough to cover, one way or another, the expenses of dependency work. This means, amongst other things, rejecting laissez-faire, neoliberal policies and imposing a level of taxation high enough to reach an effective social redistribution of the costs of caring.

Moving from domestic politics to the international level, one finds, again, strong feminist arguments in favour of the state's role in providing safety nets. While the scholarship on gender justice and globalization is not yet as developed as that on domestic welfare, feminists are likely to advocate the need for regulations to protect people efficiently from the risks of the market in the context of advancing globalization. With respect to international justice, many Western feminists reject the libertarian models of the minimal state and of unregulated markets as unfair and noxious to women who live in underdeveloped countries. Some authors such as Jaggar (2005) - make the point that neoliberal globalization is deeply harmful to women not only at the level of domestic politics, but also due to the consequences it has on women who live and work in underdeveloped countries. ${ }^{8}$ Thus, most often, neoliberalism brings poverty to women by destroying traditional industries on which they used to rely and so forcing them into the informal economy, and also by deepening their economic dependency on men - who tend to profit most from the economic changes. Effective, sufficiently strong, states, it seems, are necessary because they are powerful enough to cushion the effects of neoliberal globalization and to ensure sufficient redistribution of resources to protect women from poverty and exploitation. (It is, however, beyond the scope of this article to discuss the complex relationship between feminism and the state in the context of globalization.)

The arguments in favour of strong welfare states seem to be so intimately linked with feminist political thinking that any attempt to complicate this connection may puzzle an audience that is unfamiliar with the particularities of the gender regime in post-communist Europe. The next section offers a brief introduction to these. 


\section{The strivings towards emancipation of Romanian women}

At first glance, there are at least two reasons to think that distributive justice and care have a chance to work together successfully in Romania. Firstly, Romania inherited from the communist regime a massive welfare state whose institutions were supposed to do the job of redistributing care in society on a large scale, providing free education, health services, support for the elderly and for parents of small children. This should, however, be qualified: in spite of the existence of a welfare infrastructure, Romanian society faced a severe shortage in goods and services. Basic necessities such as food, electricity and hot water were scarce. The daycare, educational and health institutions suffered from a lack of adequate resources which prevented them from really meeting individuals' needs and often led to widespread corruption. The principles and infrastructure of the welfare state were, however, established.

Secondly, in a society whose political order has undergone deep transformations and whose institutions are being re-shaped and re-defined, ideally there should be ample opportunity for advocating an understanding of justice that is compatible with care. If care and distributive justice are indeed politically complementary values, this may be the moment for feminists in the East to make a public statement to that effect.

Unlike some other countries, such as the United States, Romania did not inherit a libertarian public understanding of justice that reserves a minimal role for the state. Moreover, like other peoples in Eastern Europe, Romanians do not have to build from scratch the infrastructure needed to support a welfare system, since it is already in place from the communist times. Or so it seems.

All this would probably be good news for Romanian feminists, possible reasons to think they do not need to fight the same battles as their colleagues in the West in order to dislocate a market-oriented, feministunfriendly understanding of justice. However, the situation is not as simple as it looks at first glance - on the contrary, it is far more sobering. In contemporary Romania, both feminists and non-feminists have good reasons to mistrust the state and its institutions.

To understand the complexities of gender and welfare in Romania (as well as in the rest of the post-communist countries, for that matter), one needs to take into consideration the historical evolution of gender politics in this region. ${ }^{9}$ The communist regime was imposed upon Romania at the end of the Second World War by Soviet power. In pre-communist Romania, women were largely dependent on men: they had no right to vote, few women were educated, and they had few economic resources. Because Romanian society was mainly agricultural, most women were deeply dependent on their families and kin. Both in the public sphere and in the private one, women were thus subordinated to men, with few resources for self-emancipation. There existed, since the late 19th century, individual feminists as well as feminist organizations, but no movement strong enough to make it possible for women to enter politics as voters or to compete economically with men. The communist regime changed this 
situation to a large extent, but it did so by focusing exclusively on the position of women in the public sphere (Magyari et al., 2001). The universal right to vote, the equality of women and men before the law, equal educational opportunities, equal pay for equal work, and equal access to employment between women and men have changed gender relations radically.

That emancipation, however, was far from complete. Political rights, for example, did not mean much under the communist one-party regime, as most of them were purely formal. ${ }^{10}$ More importantly, the image of women as natural caregivers and child-raisers did not change during the communist regime, and thus the power relations between men and women in the private sphere remained unchallenged. In turn, the division of labour within the family remained in its traditional shape, with women doing most of the household work, tending the children, the elderly, the ill and the disabled members of their families and thus bearing a double work burden (since most women were also employed).

As in most East European countries under communist rule, women's jobs in Romania were clustered in those sectors considered 'easy' (textile and food industry, education, health care, tourism) while men went into the 'hard' and more respected sectors such as extractive industries, the production of energy, petrol, transportation and communication industries. The division between 'easy' and 'hard', which was based both on physical difficulty and on social contribution, also meant that women had lower salaries and less prestige. Moreover, within each sector, women tended to be concentrated at the bottom of the hierarchy. The resulting paradox was that women, while praised as workers and mothers by the communist ideology, were in fact overworked, with smaller earnings and a lower social status than men (Einhorn, 1993; Fisher and Pasca Harsanyi, 1994; Pasca Harsanyi, 1995). Despite initial calculation, the tertiary sector turned out to be a more important and, in the long run, a more 'urban' sector than heavy industry; after 1989 the former expanded while the latter, being inefficient, had to be restructured and partially closed down. This fact plays an important role in the unfolding of this paper's arguments because the rising importance of the tertiary sector has given women unexpected chances on the post-communist market.

The gendered division of labour has been largely preserved during the post-communist transformations. However, in spite of women's inferior market position and their role in reproduction, several authors ${ }^{11}$ advanced the hypothesis that poverty in the post-communist European countries does not seem to be particularly feminized ${ }^{12}$ (Emigh et al., 1999; Pasti, 2003). This hypothesis, to which I shall return below in the section following the next, may indicate a relative (and perhaps vanishing) advantage of women in the transition from communist redistribution to capitalist markets (Emigh et al., 2001). In turn, this advantage should be taken into consideration in discussing mechanisms of redistribution and their legitimacy in post-communism. 


\section{Romanian feminists against the welfare state?}

Bearing in mind the historical context of women's partially failed emancipation during communism, and the current economic organization makes it easier to understand Romanian feminists' reasons for criticizing the welfare state. Some feminists show why the welfare state, as inherited from the communist regime, is opposed to the interests of many women. This complex subject has started to receive attention in scholarly literature. However, analytic studies that integrate the issues of women, poverty and redistribution in Romania are still missing.

Based on the research on public policy produced by sociologist Vladimir Pasti, Mihaela Miroiu's book (2004) on feminist political theory sets out to demonstrate that the welfare state in its current shape is deeply disadvantageous to women.

The Last Inequality by Pasti (2003) provides the most comprehensive analysis of the gendered aspects of economic relationships in post-communist Romania published so far. He pays special attention to the communist heritage and, in particular, to the role of the patriarchal family that survived both communism and the post-communist transition. Understanding patriarchy is essential for understanding market relationships: Pasti shows that, in spite of having incorporated traditional Romanian patriarchy, communism also brought - for the first time in Romanian history - significant legal, social and economic equality between the sexes. His analysis of the various forms of women's economic dependency during communism acknowledges the occasional economic advantages enjoyed by women. (For example, while men had a legal obligation to have a job, women sometimes had more choice in this respect since they were supposedly in charge of the family.)

An interesting hypothesis by Pasti is that a strong feminization of certain economic branches, which led to much discrimination during and after communism, also resulted in the formation of an intellectual and managerial female elite whose members played an important role in the postcommunist economic transition. Communism dismantled the traditional peasant household and brought large-scale industrialization. Its most important part, heavy industry, was largely dominated by men. The restructuring of the economy after the fall of communism (i.e. privatization and the closing down of much of the heavy industry) gave women a chance to renegotiate their place on the labour market. This opportunity, however, was largely missed due to the prevalence of misogyny in the political culture and to women's lack of political organization. Although relatively poor, women are at present, according to Pasti, the main taxpayers. Therefore, the financial resources of the Romanian (welfare) state depend on wage-earning women.

Pasti's conclusion is one of the major premises of Miroiu's book ${ }^{13}$ The Road to Autonomy, which offers (alongside a general introduction to the various feminist political theories) the original insights of the author on the importance of feminist politics in contemporary Romania. Many of these insights revolve around the difficulties of implementing policies 
beneficial to women, and identify the roots of these difficulties in the current economic structure.

Miroiu argues against what she calls 'left conservatism' and the kind of welfare state it promotes, which, she writes, works against women's best interests. Throughout her discussion of distributive policies in postcommunism, Miroiu's analysis is characterized by a tension which is never made explicit and which leads to an apparent and disturbing inconsistency. On the one hand, her criticism of the failures of the post-communist welfare state suggests she would happily advocate the feminist virtues of a better welfare state. On the other hand, she argues in favour of liberalization and, implicitly, the marketization of care. As I shall try to explain, this position has to be understood as part of her transitionalist conception of a desirable move from the current welfare arrangements towards hopefully more feminist-friendly policies. In this context, a neoliberal turn is wrongly, I believe - perceived as inevitable.

One of the distinctive strengths of Miroiu's writing is her ability to use language creatively. Over the past decade, she has introduced several new expressions which have become established terms in the current literature on political theory - feminist or not - in Romania. The most important of these terms are 'left conservatism' and 'room-service feminism'. Both terms are normatively charged and both play an important role in the unfolding of Miroiu's criticism of the Romanian welfare state.

The term 'left conservatism' refers to an allegedly typical Romanian political reality. After half a century of communism, the only possible conservative trend in Romanian politics is leftist, argues Miroiu. The reason is that the only political institutions and habits that could be preserved from the past are the communist ones. The realities of 'left conservatism' work against women's best interest: Miroiu paints the picture of a society in which the welfare state, confronted with a dire shortage of resources, redistributes poverty - not wealth - in ways that are deeply unjust to women. Most women, she argues following Pasti, work either in the official market economy - i.e. pay taxes - or in the underpaid low-prestige state sectors (that is, as social workers, as job-holders towards the bottom levels of education and health services, as caretakers in state institutions and as workers in certain industries such as the textile industry). By contrast, most of the men who were still employed by the state during the post-communist transformations earned higher wages, although the sectors in which they worked were often bankrupt (and their jobs artificially preserved for electoral reasons). Thus, the welfare state redistributes the money taxed from the 'market women' to the 'state men'; tending to the social security of the latter, the welfare state treats as secondary the highly feminized sectors. Amongst these highly feminized sectors are public health and education - that is, the welfare services that should serve women's interests by relieving some of the burdens of care from their shoulders. Because of the current economic crisis, the public expenditures for education, public health or facilities such as day-care centres are minimal. Thus the welfare state does not benefit women as it should. ${ }^{14}$

By exercising a form of 'state patriarchy', Romanian authorities prevent 
significant numbers of women from becoming the autonomous economic actors they would have become by now in a more laissez-faire regime. According to this picture, the present welfare state is redistributing money from women to men or, rather, maintaining most of its population in a state of poverty by policies that penalize women. Miroiu's conclusion is strikingly at odds with much of current Western feminist scholarship: she claims that not the welfare state, but laissez-faire economic policies would be beneficial to most women in contemporary Romania.

Arguably, one of the truly important findings of Miroiu is that the welfare state does not always promote feminist interests. Under conditions of frail and ever-changing institutions, significant levels of corruption and not entirely accountable governments, at least some women's interests may be better served by a minimal state which would allow most women to benefit from their already-gained market skills. In the last part of this article, I shall engage critically with these conclusions. Their potential attractiveness can best be understood in the context of Miroiu's stress on the value of autonomy for individual women.

As the title of her book suggests, Miroiu's conviction is that the most valuable contribution feminist politics could make to women's lives in Romania is to give them a personal sense of autonomy and the means to lead an autonomous life. But who could benefit from, and promote, feminism in Romania ${ }^{15}$ today? On the one hand, in a society that still lacks a proper middle class, most women are too poor, politically unorganized, and culturally unprepared to embrace political feminism. ${ }^{16}$ The very language of feminism, especially the one 'borrowed' from the West, is too remote from their daily struggle for subsistence. On the other hand, the small fraction of women who have the necessary education and support to lead independent lives spontaneously tend to identify with 'post-feminist' goals. They do not seem ready to organize themselves in a class of women with common and specific political goals that would be able to bring about a much-needed feminist agenda into politics. Is it too early or too late for feminism to be politically meaningful in Romania? Or, perhaps, too early for some women, too late for others?

Against this background, Miroiu coins the other term of theoretical importance in her book, 'room-service feminism' (Miroiu, 2004: 256-60). It is meant to capture the less controversial claim that feminism, like many other ideals 'imported' from abroad, is still lacking substance. The little legislation and political action that has actually benefited women was mainly introduced after external political pressure by the European Union and, for this reason, remained formal. Because of the lack of grass-roots feminist movements, feminist policy-making proceeded from the top down, failing to address the most acute problems of Romanian women. As a consequence, the type of political feminism developed in Romania was a 'room service' one, characterized by ready-made and imported agendas with very little change and participatory orientation on the part of most women.

Again, Miroiu's suggestion is that the only policies capable of advancing feminist goals are those of economic liberalism sustained by a minimal 
state, in order to help Romania achieve a level of modernization comparable to that of the Western democracies. Modernization, in turn, would create a middle class that would set the framework for any meaningful, grass-roots future feminism. One way of interpreting Miroiu's argument is by thinking about it in terms of temporal sequences. First, Romania would undergo a phase of economic growth based on liberal policies and characterized by a retreat of the old and inequitable welfare state. Hopefully, the consequence would be the formation of a class of economically successful, and thus autonomous, women. This social group then might be able to associate and to develop a genuine feminist self-consciousness as well as the material support needed for sustaining a new and just welfare state. But, as I argue below, such a strategy - even if it were successful - would involve unjust sacrifices from the most underprivileged parts of the postcommunist Romanian society. A comparative analysis will help to make this point.

\section{Women in post-communist Hungary}

How does Miroiu's account fit with the previous discussion about integrating care and justice via distributive schemes? Current Western scholarship and Romanian feminist theory seem to be pointing into completely opposite directions. In search for an answer it may be useful to look at discussions about post-communist markets, gender and welfare in another European post-communist country. Unsurprisingly, Hungarian and Romanian feminist scholarship share some insights, even though they do not draw the same conclusions regarding the welfare state.

A hypothesis advanced by recent sociological work on post-communist Europe is that women had an economic head start into the post-communist transformation. Women were discriminated against under communism by having less access than men to the labour market and by being generally locked into the underprivileged sectors of the communist economy such as the tertiary sector. They also had, during communism, less economic and political capital (membership in the communist parties was predominantly male). The side effect of this political disadvantage was that women had more time to increase their cultural and human capital, i.e. to acquire education and specific skills necessary for managing households (Fodor, 2003; Nickel, 2000, 2003: 36-7; Emigh et al., 2001). Owing to a constant shortage of basic goods on the communist market, the latter activity was far from trivial; rather, it required significant amounts of time and skill. Women's additional education and skills gave them, during the political and economical changes, better access to high positions in the banking, insurance, advertising, and tourism sectors which considerably developed after the fall of communism, unlike the heavy industries that were shut down, hitting a majority of men who were employed in these sectors.

Particularly interesting in this sense is the work of Hungarian sociologist Julia Szalai, who analyses the economic impact of the second economy - a phenomenon which was peculiar to the Hungarian society in the aftermath of the 1956 anti-communist revolution until the change of 
the regime (Szalai, 1991, 1996, 2000, 2005). Concessions made by the Hungarian authorities to private ownership of small plots and extra time claimed as welfare benefits - made possible private small businesses organized around mutual exchanges of labour and favours (Szalai, 2000). This phenomenon turned into a real second economy having the family at the centre of its economic organization. Because it was perceived as the only path towards relative independence from the absolutist central power, the economic as well as symbolic significance of the second economy was extraordinary. ${ }^{17}$ The second economy involved most of the population (three quarters of the households by the mid-1980s, according to Szalai (1996: 9)) and represented an important modernizing force (raising the quality of services developed as alternatives to badly organized state services) and making the transition to a real market economy smoother.

In the second economy, human capital was essential; efficiency and productivity required well-organized cooperation within networks that went beyond the family (Szalai, 1996: 8). Women played a crucial role in the second economy, being its organizers and managers because they, unlike men, had more possibilities to opt out (one might say 'sneak' out) of the formal economy. They were eligible for extra paid sick leave to take care of the children, maternity leave, early retirement regulations, privileges of which they took full advantage in order to participate in the second economy. Thus, women accumulated, during the last three decades of communism, important skills and knowledge (in banking, acquisition, bargaining and administration, personnel and consulting services for others in a similar situation) which proved valuable assets in the new market economy. This situation can serve as an explanatory basis for the fact that, although post-communist economic restructuring hit a majority of female jobs, in the first years of post-communism, reported and registered unemployment were lower for women than for men (Szalai, 1991, 1996: 12). Women - at least some women - thus seemed to be the winners of the transition and better adapted to the new market economy, more able to combine, flexibly, several part-time jobs. The 'marketization from below', as Szalai calls the process of transforming the second economy into a post-communist market economy, created unexpected opportunities for women (Szalai, 2000).

Not dissimilar so far to the argument made by Pasti and Miroiu, Szalai's analysis has the merit of highlighting that only some women were winners in the post-communist political and economic changes. Thus it makes possible a critical reading of Miroiu's arguments. Szalai goes further into exploring the impact made by women's withdrawal from the communist economy and their success in the second economy and then on the free market. The negative impact of the second economy on the Hungarian welfare state was twofold. First, the caregiving services organized by the second economy were far superior to those offered by state institutions; the levels of expectations rose, and the investment in alternative care services slowly took the place of investment in the state institution of caregiving. Second, the abuse of welfare benefits has further eroded the resources of the welfare state (Szalai, 1996: 7, n.3, 13; 2005). 
While rewarding those who were placed well enough to benefit from the second economy, these developments hit the population who fell outside this burgeoning sector and had to continue to rely on state-run institutions. The very characteristic that made the second economy possible - networking - served to exclude a category of people who, especially under the conditions of the 'shock therapy' adopted by Hungary as a transition strategy, gradually slipped into poverty. (Ethnic divides and the racialization of poverty accentuated the gap between rich and poor, thus creating what some sociologists call a new 'underclass', largely comprised of the Roma population (Emigh et al., 2001).) After the fall of communism, those who had the necessary connections and skills were able to accumulate more jobs, while outsiders found it increasingly difficult to find employment. Additionally, the more the institutions of the welfare state failed, the more some women's expertise in organizing caregiving was valued on the market. As a consequence, 'the success of women aspiring to middle-class positions in the expanding spheres of social services and public administration [was] generated by the failure embodied in the ever increasing numbers of "old” and “new” poor' (Szalai, 1996: 143).

Szalai's normative conclusions are strikingly different from those of Miroiu, although the empirical findings suggest an even stronger likelihood that only a new class of better-off women would benefit from the retreat of the welfare state and from liberal fiscal policies. The difference between the two bodies of scholarship (Pasti and Miroiu on the one hand, Szalai on the other) is that the latter is also concerned with issues that are not, to date, present in Romanian feminist scholarship: issues of poverty, which affects large categories of losers from the economic transitions, such as Roma (gypsies), rural populations, and populations living on the peripheries of industrial cities, who are now unemployed. There are good reasons to believe that within these populations, women are affected at least as much as men. (This is the case because they are typically responsible for dependants, and because Romanian culture continues to be patriarchal, which means that, all things being equal, women have access to fewer resources than men.)

In contrast to Miroiu, Szalai draws attention to the phenomena of accelerating poverty and ghettoization, and argues that the state must assume, once again, the responsibility for its excluded citizens. This approach is sorely needed in Romanian feminist scholarship. Roma people, who are mostly affected by these phenomena, and who represent a particular focus of Szalai's research, are not faring any better in Romania.

In this respect, Szalai identifies the current dilemma of middle-class women in Hungary as one between their economic success and solidarity with the less fortunate.

The 'women's question' is today loaded with serious class constraints. While in the West the period which shaped the agenda of modern feminism was characterised by class convergence and general prosperity, in Hungary women have to choose between economic success and solidarity. The struggles to maintain (and consolidate) the positions that many of them achieved under socialism, increasingly take the form of 'classical' class struggles. (Szalai, 1996: 43) 
Because she is aware of this dilemma - or potential conflict of interests between women who are economically successful and those who have been net losers during the post-communist transition - Szalai's analysis avoids endorsing the neoliberal agenda embraced by Miroiu. A nuanced analysis of poverty and gender politics in post-communism creates the possibility for criticizing Miroiu's version of 'feminism for the emerging middle class'. Similarly, some American feminists are criticized for giving too much weight to the interests of professional women while neglecting the interests of women who lack economic and social power (Smith, 2007).

\section{Sustainable welfare states and the extent of human dependency}

In this final section I analyse the normative relevance of the criticism of the Romanian welfare state. I conclude with an evaluation of Miroiu's proposal, arguing that the adequate solution in the face of the current weaknesses of the welfare state is its reform. Such reform is not sustainable under the conditions of liberal fiscal policies. ${ }^{18}$

As made clear by the title of her book (The Road to Autonomy), Miroiu's main concern is to advance women's autonomy by enhancing their economic position. Miroiu is not alone in detecting dependency as a particularly important threat to Romanian women. Other authors, as we have already seen, have suggested that while women in pre-communist Romania were almost entirely dependent upon the men in their families, the communist regime substituted this by dependency on the patriarchal state, thereby giving them rights but confining them to the bottom of the society. Thus, women's emancipation was far from genuine because one dependency (on men) was simply replaced with another (on the state). Magyari et al. (2001), writing on women in post-communist Romania, seem to endorse this view and to suggest that now is the time for women to attain real independence.

But is the issue at stake, and its alleged solution - liberal markets - that simple? For example, one may wonder whether the second dependency, on the state, was any better than the first. I shall not argue here in favour of the thesis that, contra the quoted authors, women under communist rule enjoyed a significantly larger degree of autonomy than before (since, although it is a plausible thesis, it is not entirely within the scope of this paper). Rather, I shall turn to the fact - which further complicates the issue of dependency and welfare - that not only women, ${ }^{19}$ but the entire society developed, under the communist regime, manifold dependencies on the state. Because it was the locus of absolute power, the state was perceived by many of its citizens as the universal potential solution to all of their problems. This, of course, is not a peculiarity of Romanian communism; one finds similar diagnoses for other former communist societies. Thus 'the tendency to rely on a patriarchal authority, in the case of East German women, was shifted from a male family member to an abstract concept of a patriarchal state, which takes care of all the citizens' needs' (Lobodzinska, 1995: 101). ${ }^{20}$

In Romania much of the criticism - feminist or not - aimed at the welfare 
state is indeed sustained by the fear of a widespread mentality of dependency. The fear is that the perception of the state as a providential and omnipotent parent, a perception that has survived the fall of communism, resulted in a general lack of initiative, including political and economic initiative. A widespread perception of the state as a universal solution, and therefore of highly paternalistic politics as legitimate, is connected with people's inability to see themselves as rights-holders and active citizens.

Miroiu's, as well as others', worries about the general lack of an entrepreneurial mentality and skills necessary for the thriving of a market economy that could sustain a welfare state are probably warranted. ${ }^{21}$ Thus women's current chance to become autonomous (from the state) can also be perceived as a civic obligation, insofar as all citizens are expected to cut themselves off from the umbilical cord to the state. But how legitimate is this expectation? And would this not, in practice, amount to sacrificing women once again? (In addition, of course, to requiring unfair sacrifices from the traditionally vulnerable social groups: the poor, the elderly, children and so on.) Interestingly, the perception that women have not only a right, but also an obligation, to become economically independent from the state in post-communism is the mirror image of the expectation, during communism, that women's right to work while the state was taking over caring responsibilities was also their political obligation. ${ }^{22}$ Ironically, in both cases, the expectation puts normative pressure on women's citizenship, rather than leaving it up to individual women to determine their work and caring responsibilities.

An important element of designing theories of distributive justice is making certain assumptions about the background conditions in which a particular model of justice is supposed to function. Rawlsian distributive justice makes sense only given a certain set of characteristics of human life. Classical examples include the scarcity of resources and the fact that many resources are rival goods - that is, goods whose consumption by one individual limits the consumption of others. Dependency does not figure on the Rawlsian list, but by revealing how dependent all of us are on care (as children, while ill and in frail old age, and some, who are disabled, for the entirety of their lives), feminists made a strong case for adding it. Kittay (1999) bases her argument for the welfare state on a model of human agency - and, as a consequence, citizenship - in which some kind of dependency represents the rule rather than the exception. The 'realpolitik' issue that Romania seems to face is how much dependency can a society 'afford'? When do welfare states become unsustainable because of too much dependency?

Let me introduce, at this point, a distinction that will hopefully carry some normative implications, between unavoidable, hence legitimate, dependency and dependencies that originate in particular social and institutional arrangements. Obviously not all dependencies are avoidable, for example those just mentioned above. Those dependencies will always be with us, and citizens who care for dependants need to be, in turn, supported by the rest of the society. In the absence of public, easily accessible institutions of caregiving, most of the primary caregivers the 
overwhelming majority of which, in Romania, are women) will continue to develop asymmetrical dependencies on their spouses or extended families, leaving them vulnerable to exploitation. Research shows that the anti-statist neoliberal turn widely embraced by Central and East European countries creates new forms of unjust dependency for women (Einhorn, 2006). ${ }^{23}$ It is beyond the scope of this article to offer a detailed analysis of Kittay's argument that caregivers have legitimate claims of support from the rest of the society. But if her conclusion - as well as many other feminists' - is correct, requiring women to assign a low priority to their dependants and to their own claims of dependency on the rest of the society is unjust, and cannot be the answer to the current welfare deadlock of Romanian and other post-communist societies. This is, in a nutshell, the strongest argument against Miroiu's defence of laissez-faire policies being part of a meaningful feminist agenda.

Another important background condition of justice one needs to take into account when thinking about dependency and welfare in Romania is the role played by the model of the family and how this influences the distribution of care. Rawlsian justice, at least in its initial formulation, assumes a model of the family in which the head of the family is the only breadwinner. As critics of Rawls (Okin, 1989) and of liberal justice in general (Pateman, 1988) have shown, implicit in this model is the assumption that the breadwinner of the family is male, and that his productivity depends on the unrecognized support of the spouse doing the housework. Even if the model were extended to that of a universal breadwinner giving women equal entry into the labour market and into politics - this would mean, in practice, that women would end up with the double burden of paid labour and household care work. Welfare proposals such as Bubeck's and Kittay's are aimed at establishing fairness in caregiving between women and men by removing much of the private caring obligations of women.

A common characteristic of both models of the family, meant to provide a background for thinking about justice in Western democracies, is that they are nuclear families. ${ }^{24}$ The nuclear family is not always present in Romania; it is still common for several generations to live under the same roof. In families where all adults are employed, childcare is often the task of grandparents - as well as much of the household work. Without denying the economic and psychological advantages of this model (that can, however, easily be romanticized and idealized), one should ask whether this is necessarily a desirable model of distributive justice. Do we want to trap women who work - and who, in the absence of adequate caregiving provisions, have to rely on relatives - in this structure? The mere fact that, given this family structure, many people with small children would 'manage' (while many would not) should not undermine the legitimacy of public institutions meant to support dependency work. An important issue to be kept in mind is that in the Romanian context, the fairness of distributing caregiving closely involves intergenerational justice. It is therefore an issue of fairness towards the grandparents' generation. How much dependency do they want to - and are able to - sustain? Equally, this is an issue 
of fairness towards parents - typically mothers - who often find themselves exceedingly indebted to and thus dependent on their parents or in-laws. The delegation of caring responsibilities to the extended family when both parents work, and its implications for intergenerational justice, are an important, and to my knowledge under-researched, issue.

To conclude, any reform of the current welfare state, if it is to conform to the requirements of distributive justice in general and to gender justice in particular, will have to encourage autonomy and a sense of reasonable responsibility for one's fate without failing to provide for legitimate dependencies. In practice, this means that the future welfare state ought to combine restructuring the non-productive industries that drain budgetary resources with enhancing its role in providing decent education and health care, re-assuming some responsibilities of care for pre-school children (state-funded day-care centres are currently extremely rare) and adequately addressing the care needs of the elderly and the disabled population.

In this respect, as already mentioned at the beginning of this paper, the proposals of Bubeck and of Kittay are inspiring. Encouraging everybody's participation in caregiving institutions for a limited period of time could be a cheaper and decentralized solution to the financial crises that most of these institutions undergo. By delegating some of the decision-making to local level, the new welfare state would sustain autonomous civic action and address legitimate dependency. While Bubeck's solution of care as a citizen's duty would address the needs of care of children, disabled and elderly persons, Kittay's suggested economic and financial advantages for primary caregivers (lower taxes, protected jobs and so on) would be a way of meeting some of the needs of those who provide most of the care in the family.

\section{Conclusions}

Can Romanian feminism still benefit from Western theory, in spite of its significantly different political experience? I argue for a positive answer. Because of its focus on urgent socio-economic realities, Miroiu's book often eludes the longer-term perspective. One important question - for the shortterm perspective - which is not adequately addressed is what would happen under the conditions of a withdrawing welfare state, coupled with laissez-faire economic policies, to those who are now entirely dependent on welfare? Another question is: what do we want in the longer run? Should we be content to have a working market economy with low taxation so that successful women can enjoy economic prosperity? Or are we going to return to the issue of the welfare state, which we will then want to be strong again, sustained by a general pro-welfare ethos? When faced with such questions, Miroiu would probably argue that, yes, in the long run we may want the welfare state back, but this is not possible before going through a phase of economic consolidation. It is, however, not clear that this transitional solution would work in practice.

Western feminist scholarship not only makes a case that proper distributive justice has to include care, but it also shows how difficult it is to 
argue in favour of state mechanisms for redistributing care when one departs from a status quo which does not acknowledge the link between care and justice. After half a century of communist ideology, Romanian scholars are inclined to take for granted the existence of the welfare state and feel intellectually free to question its legitimacy. The experience of the Western feminist political debate is relevant in two ways. First, it offers normative models which help us to reflect on what political goals we want to reach in the longer term. Second, Western feminist political debate points to the other side of the story: the difficulty of legitimizing the welfare state, from a feminist standpoint, to the satisfaction of those who are attached to the ideal of a minimal state.

\section{Notes}

I am very grateful to several people for valuable feedback on successive drafts of this paper: Pamela Anderson, Ioana Borza, Eniko Demeny, Julieta Elgarte, Nanette Funk, Axel Gosseries, Alina Silian, Ann Snitow, Julia Szalai and Alexander Vezenkov, as well as to the participants in conferences in Sarajevo, Bremen, New York and London where I presented my work. Warmest thanks to the anonymous reviewers from Feminist Theory for their detailed and encouraging comments.

1. For sociological work done by feminists on the institutional arrangements of welfare states that would best accommodate the interests of women as parents and workers see Lister (2003 [1997]), Williams (2000), Gornick and Meyers (2003), Pascall and Lewis (2004).

2. Throughout this article, I choose to use the word 'communism' to refer to the period between the end of the Second World War, when the Soviet Union imposed its political regime in Romania, Hungary and other countries, and 1989. Thus, 'post-communism' refers to the post-1989 developments. The choice has no ideological implication. (I do not claim, for example, that countries in Eastern Europe knew the only, and even less the best possible, form of communism.) The alternative would be to refer to 'state socialism' instead of 'communism'. This would, however, carry the risk of confusion between different (East and West) European models of socialism and would make less clear the distinction between communism and post-communism, which is important for the arguments I develop.

3. 'Laissez-faire' is a term widely used by the Romanian author Mihaela Miroiu - whose work I discuss extensively in this paper - to refer to the neoliberal paradigm of liberalization that has been embraced, to various degrees, by post-communist countries in Central and Eastern Europe.

4. For example, see the work of Julia Szalai, which I discuss in a subsequent section.

5. For a very recent and compelling argument of why justice demands the redistribution of some of the work of care, and why a civilian service is the best means to bring about such redistribution, see Fabre (2006).

6. For a detailed analysis of the criteria that such arrangements should meet in order to be just to women, see Fraser (1994).

7. This is a topic of wide interest in feminist literature. For a concrete proposal of how we might implement a double-earner-double-carer 
model (or, according to Fraser's terminology, a universal caregiver model) see Gornick and Meyers (2003). For a discussion of how the introduction of a universal basic income would affect gender justice, by giving women a real choice between working on the market and being homemakers, see Robeyns (2001).

8. The positions taken by feminists on issues of global justice are of course varied, and I do not aim here to give a comprehensive picture.

9. For a general argument explaining why feminist consciousness and feminist politics could not arise in the former communist countries of Europe, see Watson (1997).

10 Some authors, such as Miroiu (1999, 2004), claim that political rights meant nothing, since all citizens were equally impotent in the context of a totalitarian regime. This may be right in some respects: the right to vote, for example, was insignificant since electoral results were predetermined. However, people with important positions in the Communist Party, as well as those in local administrations, had special access to resources and were richer than normal citizens in terms of material and human capital. Some of these people were women (although fewer than men) and thus it is reasonable to argue that women did have some political power - at least more than they ever had in Romanian history.

11 Like Miroiu and Szalai whose work I discuss here at length, Emigh et al. (1999) note that, while politically discriminated against during state socialism, women were promoted to high positions in the tertiary sector banking, insurance, advertising, tourism - and thus developed good human and social capital. This helped women to avoid unemployment and even to find good jobs in the new economy. Hence, at least initially, the transition from state socialist to market economy benefited women. However, these authors also note that things are changing rapidly with young men entering the market and it may take less than a generation for women's initial relative advantage to erode (Emigh et al., 1999: 8-9).

12 This claim, which is supported by research done in Eastern and Central Europe and discussed in Emigh et al. (2001), has been challenged by Romanian scholars to the extent to which some of women's poverty may be found within households; that is, the distribution of resources within the family may be unfair to women. The same point was made by Miroiu (2004) concerning the distribution, within the family, of essential and scarce resources (like food) during the most under-resourced years of communism. The degree of the feminization of poverty probably varies across different post-communist countries. With respect to their presence on the job market, for example, the rates of unemployment in Romania between 1991 and 1997 were higher for women than for men (Magyari et al., 2001), while in Hungary they were not (Szalai, 1996).

13 Miroiu (1999, 2004) introduced feminist studies into Romanian academe and was the first to publish in feminist philosophy and political theory after the fall of communism.

14 At the same time, with the pauperization of education in post-communist Romania, women's access to the top has become easier in the past few years. This is a hypothesis advanced by Popescu (2004: 129), as well as by a recent study on education by Stefanescu (2003).

15 For the difficulties that women face in other post-communist countries to 
find meaningful ways of organizing themselves around a feminist agenda see, for the case of the Czech Republic, Havelkova (1993, 2000).

16 For the background hardships of developing feminist politics in Romania, see Roman (2001).

17 See Szalai (1996) for an analysis of how the divide between public and private as a distinction between 'us' and 'them', and the importance of the family as the only space of liberty, contributed to the expansion of the second economy.

18 Other authors have already argued in favour of a reform, rather than abolition, of the welfare state in the former communist countries. See for example Pascall and Lewis (2004) and Einhorn (2006).

19 For the argument that women from (post-)communist societies in particular have been lacking in autonomy, and the resulting conflicts between Western and Eastern feminisms - especially between feminists in the former East and West Germany - see also Dölling (1991), Einhorn (1993) and Marx-Ferree (1995).

20 For the argument that socialist modes of production have deeply shaped dependent and passive attitudes among those involved in them, see Verdery (1996).

21 One may add that it is equally reasonable to worry about the lack of trust and solidarity which would be necessary for the working of a socialist regime, but this political option is definitely excluded by the current elites. The Romanian post-communist intellectual climate is deeply hostile to egalitarian politics; some of the reasons have to do with fears of perpetuating individuals' dependency on the state, with the perceived danger of the state's interference into the private life of individuals and with the loss of individual merit and individual responsibility. An analysis of the reasons for this, however, is outside the scope of this paper.

22 I am thankful to an anonymous reviewer of this journal for this insight.

23 See especially the last chapter of Einhorn's book, which also contains a critique of our reliance upon the blooming civil society to take over caring responsibilities.

24 Interestingly, the alternative and more feminist models discussed by various scholars - such as the caregiver parity (Fraser, 1994) or double-earner-double-carer model (Gornick and Meyers, 2003) - also take as a premise the nuclear family, since they are mainly intended to model Western social realities.

\section{References}

Alstott, A. (2004) No Exit: What Parents Owe their Children and What Society Owes Parents. Oxford: Oxford University Press.

Bubeck, D. (1995) Gender and Justice. Oxford: Clarendon Press.

Bubeck, D. (1999) 'A Feminist Approach to Citizenship’, pp. 401-28 in O. Hufton and Y. Kravaritou (eds) Gender and the Use of Time. Dordrecht: Kluwer Academic Publishers.

Dölling, I. (1991) 'From Hope and Helplessness: Women in the GDR after the Turning Point', Feminist Review 39: 3-15.

Einhorn, B. (1993) Cinderella Goes to Market: Gender, Citizenship, and Women's Movements in East Central Europe. London and New York: Verso. 
Einhorn, B. (2006) Citizenship in an Enlarging Europe: From Dream to Awakening. New York: Palgrave Macmillan.

Emigh, R., E. Fodor and I. Szelenyi (1999) 'The Racialization and Feminization of Poverty during the Market Transition in the Central and Southern Europe', European University Institute working paper 99/10.

Emigh, R. J., E. Fodor and I. Szelenyi (2001) 'The Racialization and Feminization of Poverty?', pp. 1-32 in R. J. Emigh, E. Fodor and I. Szelenyi (eds) Poverty, Ethnicity and Gender in Eastern Europe during the Market Transition. Westport, CT and London: Praeger.

Fabre, C. (2006) Whose Body is it Anyway? Justice and the Integrity of the Person. Oxford: Oxford University Press.

Fisher, M. E. and D. Pasca Harsanyi (1994) 'From Tradition and Ideology to Elections and Competition', pp. 168-95 in M. Rueschemeyer (ed.) Women in the Politics of Postcommunist Eastern Europe. London: M.E. Sharpe.

Fodor, E. (2003) Working Difference: Women's Working Lives in Hungary and Austria. Durham, NC: Duke University Press.

Fraser, N. (1994) 'After the Family Wage: Gender Equity and the Welfare State', Political Theory 22: 591-618.

Gornick, J. C. and M. K. Meyers (2003) Families that Work: Policies of Reconciling Parenthood and Employment. New York: Russell Sage Foundation.

Havelkova, H. (1993) 'A Few Pre-feminist Thoughts', pp. 62-73 in N. Funk and M. Mueller (eds) Gender Politics and Post-Communism. New York and London: Routledge.

Havelkova, H. (2000) 'Abstract Citizenship? Women and Power in the Czech Republic', pp. 118-38 in B. Hobson (ed.) Gender and Citizenship in Transition. New York: Routledge.

Jaggar, A. M. (2005) 'Western Feminism and Global Responsibility', pp. 150-88 in B. S. Andrew, J. Keller and L. H. Schwartzman (eds) Feminist Interventions in Ethics and Politics. Lanham, MD: Rowman and Littlefield.

Kittay, E. F. (1999) Love's Labor: Essays on Women, Equality, and Dependency. New York: Routledge.

Lister, R. (2003 [1997]) Citizenship: Feminist Perspectives. New York: New York University Press.

Lobodzinska, B. (1995) 'Germany (Former German Democratic Republic)', pp. 101-11 in B. Lobodzinska (ed.) Family, Women and Employment in Central-Eastern Europe. Westport, CT: Greenwood Press.

Magyari, N. L., E. Magyari-Vincze, L. Popescu and T. Rotariu (2001) 'The Social Construction of Romanian Poverty: The Impact of Ethnic and Gender Distinctions', pp. 123-56 in R. J. Emigh, E. Fodor and I. Szelenyi (eds) Poverty, Ethnicity and Gender in Eastern Europe during the Market Transition. Westport, CT and London: Praeger.

Marx-Ferree, M. (1995) 'Patriarchies and Feminisms: The Two Women's Movements of Post-Unification Germany', Social Politics 2(1): 10-24. Miroiu, M. (1999) Societatea retro [The Retro Society]. Iasi: Editura Trei. Miroiu, M. (2003) 'State Men, Market Women: The Effects of Left Conservatism on Gender Politics in Romanian Transition’, paper presented at Indiana University, Bloomington, Indiana.

Miroiu, M. (2004) Drumul catre autonomie. Teorii politice feministe [The Road to Autonomy: Feminist Political Theories]. Iasi: Polirom. 
Nickel, H. M. (2000) 'Employment, Gender and the Dual Transformation in Germany', pp. 106-22 in C. Flockton, E. Kolinsky and R. Pritchard (eds) The New Germany in the East: Policy Agendas and Social Developments since Unification. London: Frank Cass.

Nickel, H. M. (2003) 'The Future of Female Employment: A Gendered Gap in Political Discourse', pp. 31-52 in E. Kolinsky and H. M. Nickel (eds) Reinventing Gender: Women in Eastern Germany since Unification. London: Frank Cass.

Nussbaum, M. (2006) Frontiers of Justice: Disability, Nationality, Species Membership. Cambridge, MA: Harvard University Press.

Okin, S. M. (1989) Justice, Gender, and the Family. New York: Basic Books.

Pasca Harsanyi, D. (1995) 'Participation of Women in the Workforce: The Case of Romania', pp. 213-18 in B. Lobodzinska (ed.) Family, Women, and Employment in Central-Eastern Europe. Westport, CT: Greenwood Press.

Pascall, G. and J. Lewis (2004) 'Emerging Gender Regimes and Policies for Gender Equality in a Wider Europe', Journal of Social Policy 33(3): 373-94.

Pasti, V. (2003) Ultima inegalitate. Relatiile de gen in Romania [The Last Inequality: Gender Relationships in Romania]. Iasi: Polirom.

Pateman, C. (1988) The Sexual Contract. Stanford: Polity Press.

Pfau-Effinger, B. (2005) 'New Forms of Citizenship and Social Integration in European Societies', pp. 189-204 in J. Andersen, A. M. Guillemard, P. H. Jensen and B. Pfau-Effinger (eds) The New Face of Welfare: Social Policy, Marginalization and Citizenship. Bristol: Policy Press.

Popescu, L. (2004) Politica sexelor [The Politics of the Sexes]. Bucuresti: Maiko.

Robeyns, I. (2001) 'Will a Basic Income do for Women?', Analyse und Kritik 23(2): 88-105.

Roman, D. (2001) 'Gendering Eastern Europe: Pre-feminism, Prejudice and East-West Dialogues in Post-Communist Romania', Women's Studies International Forum 24(1): 53-66.

Smith, A. M. (2007) Welfare Reform and Sexual Regulation. New York: Cambridge University Press.

Stefanescu, D. O. (2003) Dilema de gen a educatiei [The Gender Dilemma of Education]. Iasi: Polirom.

Szalai, J. (1991) 'Some Aspects of the Changing Situation of Women in Hungary’, Signs 17: 152-70.

Szalai, J. (1996) 'Two Studies on Changing Gender Relations in Post-1989 Hungary'. Working Papers Series. Collegium Budapest.

Szalai, J. (2000) 'From Informal Labor to Paid Occupations: Marketization from below in Hungarian Women's Work', pp. 200-24 in S. Gal and G. Kligman (eds) Reproducing Gender: Politics, Publics, and Everyday Life after Socialism. Princeton: Princeton University Press.

Szalai, J. (2005) 'Poverty and the Traps of Postcommunist Welfare Reforms in Hungary: A Fourth World of Welfare on the Rise?', unpublished manuscript.

Tronto, J. (1993) Moral Boundaries: A Political Argument for an Ethic of Care. New York: Routledge.

Verdery, K. (1996) What Was Socialism, and What Comes Next? Princeton: Princeton University Press.

Watson, P. (1997) 'Civil Society and the Politics of Difference in Eastern Europe’, pp. 21-9, in J. W. Scott, C. Kaplan and D. Keats (eds) Transitions, 
Environments, Translations: Feminisms in International Politics. New York and London: Routledge.

White, J. and J. Tronto (2004) 'Political Practices of Care: Needs and Rights', Ratio Juris 4: 425-53.

Williams, J. (2000) Unbending Gender: Why Family and Work Conflict and What to do about It. Oxford: Oxford University Press.

Anca Gheaus is currently a postdoctoral researcher at the Universite Catolique de Lille and a visitor at the Centre for the Study of Social Justice, University of Oxford. Recent publications include 'What Would a Basic Income Do for Gender Justice?', in Basic Income Studies 3(3) (forthcoming 2008); 'How Do Theories of Care Challenge Ideal Theories of Distributive Justice?', in Lisa Tessman (ed.) Feminist Ethics and Social and Political Philosophy: Theorizing the Non-Ideal (Kluwer Academic Publishers, forthcoming 2009); 'How Much of What Matters Can We Redistribute?', in Hypatica 24(4) (forthcoming 2009); and 'Is Unconditional Forgiveness Ever Just?', in Pamela Sue Anderson (ed.) New Topics in Feminist Philosophy of Religion: Resistance, Religion and Ethical-Political Relations (Kluwer Academic Publishers, forthcoming 2009).

Address: Thierschstrasse 44, D 80538 Munich, Germany. Email: agheaus@gmail.com 